\title{
The Impact of Critical Discourse Analysis in Political Speeches
}

\author{
Jelena Žanić Mikuličić
}

\begin{abstract}
The aim of this paper is to compare and discuss, by means of critical discourse analysis, linguistic devices used by Scottish First Minister Alex Salmond and British Prime Minister David Cameron in campaign which took part before Scottish referendum for independence, held on 18th September 2014. Their speeches were extracted from the on-line editions of the newspapers The Scottish Independence and The Guardian. The Scottish referendum for independence failed to pass due to lack of Salmond's persuasive speech power and the fact that the voters did not want to change their present status in the Union since it has been functioning well through the years.
\end{abstract}

Keywords - politics, power, critical discourse analysis, political speech, positive self- and negative other-presentation, lexical devices.

\section{INTRODUCTION}

$\mathrm{S}$ PEECH and power of persuasion are some of the most important tools and techniques of politics. Through the political speech one expresses an existing idea to the audience. Politics does not mean only governing the country but it is a subtle game of persuasion, power and playing and that is the reason why political speeches and persuasion techniques are very important.

Political discourse analysis is critical discourse analysis (CDA), based on social sciences and linguistics. It is not a homogenous model, but combination of linguistics, semiotic or discourse analysis [1]. This author also states that CDA concentrates on the abuse of power especially on dominance and the way it can control people's beliefs and actions to suit the interests of dominant groups [1]. Language is the means through which the political power becomes more comprehensible to the audience [2]. Persuasion and manipulation are combined with legitimation when one group or one politician wants to impose his/her opinion and domination over the other group or politician [3. For CDA language is not powerful on its own, but there are certain powerful people who make it so [2].

Norman Fairclough developed a three-dimensional framework for studying discourse. He uses micro-, mediumand macrolevel interpretation. Micro-level stands for the textual analysis, the medium-level means studying issues of

production and consumption and macro-level includes

Jelena Žanić Mikuličić is with the Faculty of Maritime Studies Croatia intertextual and interdiscursive elements of the self or other presentation which means power and dominance between social groups [1].

Political discourse analysis explains political power abuse or domination through political discourse. Such analysis deals with the "discursive conditions and consequences of social and political inequality that results from such domination". "Those groups who control most influential discourse also have more chances to control the minds and actions of others" [1].

\section{AIM}

The aim of this paper is to compare and contrast the speeches of two politicians of politically opposite parties with a view of establishing whose persuasion techniques, argumentation and messages of the two speakers proved to be more successful. We focused on the speech of the then Scottish First Minister Alex Salmond and British Prime Minister David Cameron. Through the study of their speeches and by means of critical discourse analysis we will establish if the Scottish referendum for independence, held on 18th September 2014, failed to pass due to lack of Salmond's persuasive speech power. The analysis will try to show how much persuasive power the speeches have and how they can influence changes in society, in this case, how it influenced Scottish citizens to vote "pro" staying in the Union with Great Britain.

\section{MethodOLOGY}

The methodology in this paper draws on critical discourse analysis and macro level analysis of discursive practice according to Fairclough [5]. Comparison, contrast and interpretation of discourse will be made according to the politicians' speech methods and techniques that they used (positive self-presentation and negative other-presentation). Speeches and cites of First Minister of Scotland Alex Salmond and British Prime Minister of Conservative Party David Cameron were extracted from the on-line editions of the newspapers The Scottish Independence and The Guardian.

\section{Political System IN THE United Kingdom}

Scotland and England became the part of political union in 1707 and the part of the British parliament. In the Scottish Parliament, the Scottish National Party (SNP) has government and majority of seats. Opposition parties are the Scottish Labour Party, the Scottish Conservative Party, the Scottish 
Liberal Democrats and the Scottish Green Party. On 18th September 2014 in the referendum for independence, Scots voted to stay part of Great Britain. After the failure, Alex Salmond, who led the SNP for over twenty years, resigned. [6]. The United Kingdom of Great Britain and Northern Ireland is a unitary democracy. In 1801, the name the United Kingdom of Great Britain and Northern Ireland was adopted. There are two largest political parties; the Conservative Party and the Labour Party. A Conservative-Liberal Democrat coalition ended in 2015, when the Conservative Party with its Prime Minister David Cameron won the majority [7].

\section{POLITICAL SPEECHES IN THE CAMPAIGN FOR SCOTTISH INDEPENDENCE}

During the campaign both ministers established communication with the public, masses and media. In order to attract the attention of the voters each speaker established his own style of speech by using linguistic means such as metaphors, simile, positive self-presentation and negative other-presentation. Lexical means will be put in italic and described through the analysis

\section{POLITICAL SPEECH OF SCOTTISH PRIME MinISTER ALEX SALMOND}

Alex Salmond made his speech on currency union and independence on 17th February 2014 in Edinburgh. For the purpose of this paper, the speech was taken from the web site of The Scottish Government [8]. The speech has 20886 characters with spaces. We mentioned those parts of the speech which have linguistic means of persuasion and lexis by which the speaker tries to attract the masses. Salmond's speech contains both positive self-presentation and negative otherpresentation language devices which intertwine with the speech topics introduced at the very beginning.

1) Firstly, I want to emphasize that contrary to the destructive campaigning style and rhetoric of the Westminster establishment, the Scottish Government will continue to be constructive and positive about the future of this country. I believe that a positive campaign will always win out over a negative campaign and I also believe that attempts to dictate from on high the terms of the debate underrate the strength of the democratic process on which we are engaged in Scotland. They also badly misread the nature of Scotland and the character of the Scottish people. Secondly I want to address the specific arguments made by the Tory Chancellor to justify his opposition to our proposal of a currency union between the rest of the UK and an independent Scotland. Thirdly I will discuss the politics of why that currency intervention of the Westminster parties acting in concert has already backfired so badly. And fourthly I will argue not only that Scotland could be an independent country, but that we should and indeed must become independent if we are to provide the economic and social advances the people who live here deserve.

- The speaker divides his speech in four themes and makes an introduction to each of them. He starts his speech with negative other-presentation by emphasizing that the opponent's campaign is destructive in its rhetoric which is not going to be a case with his campaign. Still, he does not explain in which way Cameron's campaign is destructive. On the other hand, he and his government are constructive and future oriented. He believes that the British government cannot know Scottish people better than the Scottish one. In the sentence they misread the nature of Scotland and the character of the Scottish people, Salmond strengthens his relationship with his people and shows the attitude that he is someone who understands them because he is not a foreigner. Through this part of the speech, Salmond gives examples of positive selfpresentation. He also encourages divisions. Economic and social growth can be possible only if they are the independent country. So, the speaker emphasizes the independence as imperative without which everything would collapse. In other words, it would be a failure to reject the opportunity to be independent.

2) After the SNP's victory in the 2011 election the Westminster government, initially at least, demonstrated a welcome spirit of co-operation. Of course there were some exceptions to that rule. When visiting the North East of Scotland in November 2011 the Chancellor of the Exchequer declared that he knew that merely having the referendum was putting-off inward investors. Since then inward investment has surged to new highs in Scotland and our unemployment rate is now 6.4 per cent compared to the UK average of 7.1 per cent. Mind you these are small errors compared to most Treasury forecasts!

- In this part of the speech, the speaker reminds the audience of past events. Once the government was ready for cooperation and later on the finance minister gave statements in which he tried to frighten Scots. He says that the Westminster government showed a welcome spirit only at the beginning of the victory of the SNP and in this way he emphasizes the opponent's false modesty and maybe unwillingness to cooperate. He gives statistics on unemployment rate and makes comparison to the average unemployment rate of the UK; our unemployment rate is now 6.4 per cent compared to the UK average of 7.1 per cent. The speaker tries to refute the fact that the foreign investments will disappear if Scotland becomes independent. This part of the speech is very important because social and economic issues are topics that mostly evoke interest in the citizens. He does it with mentioning numbers, giving concrete data because he, as a politician, knows that people believe statistics and he tries to gain their attention in this way. The speaker indicates mistakes in assessments and forecasts of the British Government because the results are far much better. The speaker in this way encourages the voters and tries to convince them that they can be economically stable.

3) However in 2012 the Prime Minister and I signed the Edinburgh Agreement to ensure the referendum on independence would take place in a legal and consensual manner. In that agreement both governments vowed to respect 
the result of the referendum, whatever the outcome, and to work together constructively in the best interests of the people of Scotland and the rest of the United Kingdom. (...) In the event of a yes vote that spirit of constructive cooperation will indeed take place. After all, it is in everyone's mutual interest for that to happen.

- In this part, the speaker presents positively his and Cameron's government by saying that both sides were willing to do this in a legal and consensual way. The conjunctive adverb however at the beginning of the speech indicates that despite the Chancellor of the Exchequer's statement and his socalled bad results and predictions, Cameron and his party decided to sign the agreement on referendum. Both sides signed that they would respect the referendum i.e. the will of people, because citizens of the United Kingdom are the most important citizens to them. In this part of the speech, the speaker uses interesting lexis such as mutual interest, work together constructively in the best interest of the people of Scotland, constructive cooperation. With these expressions he actually emphasizes importance of togetherness, still believing that independence is possible and that Yes vote will happen. He does not give up this plan, but the opponent changes his attitude, makes divisions and does not want to follow the signed agreement. In this part of the speech, Cameron's actions are presented positively but in the next part of the speech Salmond shows the opponent's fickleness. His rhetorical tactics is that the negative other-presentation follows after positive one.

4) However we are now in a campaign period and the Conservative-Liberal Democrat Westminster government has abandoned co-operation and that has been echoed by figures in the Labour Party who should know a great deal better. For example on Thursday George Osborne ${ }^{1}$ peppered his speech with references to Scotland as a "foreign country". Let me be clear. For Scots whether independent or not, the rest of the UK will never be "foreign". Indeed the Government of Ireland Act of 1948, negotiated after infinitely more difficult circumstances than we have, specifically states that Ireland is not to be regarded as a "foreign country". And so despite the Chancellor's campaign rhetoric I don't believe his "foreigner" language represents any significant view in Scotland or indeed England, Wales and Northern Ireland. Then there's the UK diplomatic offensive against independence. A previous Foreign Office Permanent Secretary once told me that we should regard the Foreign Office as Scotland's Foreign service. Clearly not now!

- The speaker claims that the government will not always be willing to do everything in a cooperative manner. There is no cooperation because Cameron does not respect the agreement. Cameron cannot lose Scotland and the Labour Party does not

\footnotetext{
${ }^{1}$ George Osborne is a British Conservative Party politician. He entered Parliament as the youngest Conservative MP in the House of Commons. In 2010 he became The Chancellor of the Exchequer. 'He is the government's chief financial minister, responsible for raising revenue through taxation or borrowing and for controlling public spending. He has overall responsibility for the work of the Treasury."
}

want to cooperate. In order to highlight negative otherpresentation he uses the verb pepper which he connects with George Osborne's speech ${ }^{2}$ and his mocking way of speaking about Scotland as a foreign country. Osborne thinks about Scotland as a foreign country but Britain is still not willing to let it be independent. By repeating the word foreign in foreign country, foreigner, foreign office, the speaker wants to express his disappointment with the opponents and emphasizes his modesty and respect towards the UK by saying that Britain will never be foreign for Scots. These words show his belief in the independence which will not disrupt their good relations.

5) And in the last few days, panicky briefings suggest that even a Yes vote on September 18 might not be respected in direct contradiction of not just the spirit but the letter of the Edinburgh Agreement. I have asked the Prime Minister to repudiate any such suggestion, promptly and categorically or better still, let me put it to him directly in a debate - perhaps in this very city of Aberdeen next week. With all this accumulated negativity, it is little wonder the no campaign calls itself Project Fear. But we should be clear that what is said by Westminster during the heat of a political campaign will differ from the reality of life after the referendum. In the event of a yes vote the campaigning will stop and the commonsense agreements will start.

- The speaker uses negative other-presentation and lexis which is seen in the words panicky briefing or accumulated negativity. With these terms he intimidates the audience in order to show how hypocritical the British government can be. The expression panicky briefings refers to those who are spreading the panic but Salmond does not give specific names of them. He confirms his uncertainty by using the modal verb might not. He believes that common-sense agreement will be respected. He tries to convince the voters that the British government will not behave according to the signed agreement. He is convinced (and conveys it to the audience by using pronoun "we") that things will not change for better and that the Westminster promises will not be realized. He prepares his audience to distinguish between what is said in the campaign and what will follow.

\section{POLITICAL SPEECH OF BRITISH PRIME MINISTER DAVID CAMERON}

David Cameron made his speech on currency union and independence on 28th of August 2014 in London, in the Olympic Park. For the purpose of this paper, the speech was taken from the web site of The Guardian [10] and it has 5459 characters with spaces. We extracted those parts of the speech which contain persuasion devices by which the speaker tries to

\footnotetext{
${ }^{2}$ George Osborne's part of speech on Scotland and the Pound: "So when the nationalists say "the pound is as much ours as the rest of the UKs" are they really saying that an independent Scotland could insist that taxpayers in a nation it has just voted to leave had to continue to back the currency of this new foreign country had to consider the circumstances of this foreign country when setting their interest rates stand behind the banks of this foreign country as a lender of last resort or stand behind its foreign government when it needed public spending support."[9].
} 
attract the masses. The speech is more positive selfpresentation than negative other-presentation oriented.

1) $90 \%$ of Scottish financial services' customers live in England, Wales and Northern Ireland, while Scotland's famous computer gaming industry and its "cutting-edge sub-sea technology" benefit from selling across the UK without transaction costs. This is one of the oldest and most successful single markets in the world. Scotland does twice as much trade with the rest of the UK than with the rest of the world put together - trade that helps to support one million Scottish jobs. This success doesn't happen by accident. It happens because of the skill of people in Scotland and the opportunities that come from being part of something bigger, a large domestic market, underpinned by a common currency, common taxes, common rules and regulations, with no borders, no transaction costs, no restrictions on the flow of goods, investment or people. Ours really is an economy of opportunity. We spend some $£ 33$ bn a year on defense, and over $£ 2 b n$ a year for the security and intelligence agencies and National Cyber Security Programme. An independent Scotland would not be able to share these agencies. It would have to build its own infrastructure - and pick up the bill.

- The speaker starts his speech with the topic that will be the most important to the voters and will certainly influence their opinion and that is economy. He praises Scotland and its computer gaming industry (most successful single markets in the world) from which Scotland can only benefit. So, if someone will lose the game if Scotland votes "yes", those are the Scots because the trade helps to support one million Scottish jobs. He praises Scots as being very skilled people who had and still have opportunity to develop more if they are part of something big (here he is thinking of Great Britain). He actually wants to say that they would not be so successful without the Union and lures the voters by speaking about large domestic market, underpinned by a common currency, common taxes, common rules and regulations, with no borders, no transaction costs, no restrictions on the flow of goods. He insists on togetherness without divisions. With his sentences he tries to convince the voters that there are still benefits of staying in the Union. The economy which Britain offers is the economy of future i.e. opportunity. Here, the speaker implies that without the Union there is no more prosperity for Scotland. Scotland is now successful in its financial services only because it has been the member of the Union for three hundred years. Interesting is the idiom pick up the bill, which would mean that maybe Scotland alone would be successful one day but the way to the top would be hard and expensive without the Union. Scotland will have to bear consequences of its decisions and build everything from the beginning. In this way he tries to evoke positive feelings in the audience, make them think twice and for this purpose he uses the speech act of warning. In this part of the speech, the speaker praises Scots, shows that he insists on togetherness and mentions the consequences of leaving the Union.
2) Here is that 'Vow' that all three party leaders ${ }^{3}$ agreed just four days ago. The implications of the referendum next autumn will affect not just Scotland, but England, Wales and Northern Ireland. However, the UK already has a different relationship with the EU than the other member states. It gets a significant rebate on its financial contributions to the EU budget; it has external borders with other EU member states; it has its own currency; it did not sign the fiscal stability treaty which requires budget prudence and introduces a debt brake for the 17 Eurozone states; and it will not (unlike 11 Eurozone states) impose a financial transaction tax which is designed to discourage speculative trading.

- In the sentence The implications of the referendum next Autumn will affect not just Scotland, but England, Wales and Northern Ireland, the speaker explains that Scotland is not alone in this union. He implies that there will be some consequences if Scotland succeeds but he does not name the culprit. This is again Cameron's act of warning Scots. So, they need to be empathetic and think also of the other states that would be affected with this referendum. He wants to say that Scotland is responsible for the other parts of the United Kingdom. He attracts the audience by mentioning UK's different relationship with Europe, meaning that Britain does not depend on anyone. He brags about the financial security that they built through all these years, own currency and stability that the Union has. He shows his power by mentioning all benefits that they enjoy as the unique state in the European Union. With this way of speaking, emphasizing the benefits, mentioning stable economy, describing the Union and Scotland as an unbreakable bond, Cameron tries to gain his goal. In this part of the speech, he points out the advantages of being the part of the Union. He also thinks about the other member states which would lose everything and even Scots would not live well anymore. By mentioning financial data, the speaker emphasizes the advantages of staying in the Union. His informative speech act shows assertive persuasive strength.

3) Those glorious Olympics last summer reminded us just what we were capable of when we pull together: Scottish, English, Welsh and Northern Irish, all in the same boat sometimes literally. If you told many people watching those Olympics around the world that we were going to erect barriers between our people, they'd probably be baffled. Put simply: Britain works. Britain works well. Why break it?

- With this part of speech he acts on the emotions of the audience. According to his speech the Olympics were glorious thanks to togetherness. There is no such country that could cooperate as well as Britain. His simple sentences Britain

\footnotetext{
${ }^{3}$ The leaders of the UK's three main political parties have signed a pledge to give more powers to Scotland if it rejects independence. In the joint letter, the party leaders agree that "the UK exists to ensure opportunity and security for all by sharing our resources equitably across all four nations". The letter also states: "Because of the continuation of the Barnett allocation for resources and the powers of the Scottish parliament to raise revenue, we can state categorically that the final say on how much is spent on the NHS will be a matter for the Scottish parliament."
} 
works. Britain works well. Why break it?show his belief in needlessness to change present condition which is, according to his opinion, more than satisfactory. Nothing will be the same if they split apart. In his speech, he returns to the Olympics by mentioning how capable the nation was when working together, everything was good and now Scotland wants barriers. He addresses the audience as if he does not know why this happens and tries to get the answer. In this way Cameron tries to reach his voters and their feelings by reminding them of great days they had together and by showing his sadness if they split apart.

4) Sometimes we can forget just how big our reputation is, that the world over the letters 'UK' stand for unique, brilliant, creative, eccentric, ingenious. We come as a brand - a powerful brand. Separating Scotland out of that brand would be like separating the waters of the river Tweed and the North Sea. If we lost Scotland, if the UK changed, we would rip the rug from under our own reputation. The plain fact is we matter more in the world together. Our reach is about much more than military might - it's about our music, film, TV, fashion. The UK is the soft power superpower you get teenagers in Tokyo and Sydney listening to Emeli Sandé; people in Kazakhstan and Taiwan watching BBC exports like Sherlock, written by a Scot a hundred years ago, played by an Englishman today, and created for TV by a Scotsman. I passionately hope that my children will be able to teach their children the same - that the stamp on their passport is a mark of pride. That together, these islands really do stand for something more than the sum of our parts, they stand for bigger ideals, nobler causes, greater values. This is our home - and I could not bear to see that home torn apart. I love this country. I love the United Kingdom and all it stands for. And I will fight with all I have to keep us together.

- This part of Cameron's speech is especially touching and appeals to pathos. He uses very powerful rhetorical devices for the Union and it is the metaphor brand. When the country is known as the brand then no one can let it go so easily. Very important is his simile by which he emphasizes the impossibility of separation-Separating Scotland out of that brand would be like separating the waters of the river Tweed and the North Sea. He often uses the pronoun "we" and highlights constantly the fact that without Scotland there is no Britain. The pronoun we in this part of his speech stands for the United Kingdom and not for him and his government alone. He uses pronoun I rarely through his speech. With the metaphor we would rip the rug from under our own reputation the speaker gives full attention to Scotland and its voters. In this manner he sends the message that Britain would be doomed to fail without Scotland and again, such emotional approach brings him closer to the audience. In this context he says that the UK is the soft power superpower and with mentioning actors and singers he emphasizes how powerful its popular culture is all over the world. Cameron approaches the audience by using simile and he constantly emphasizes the importance of togetherness, cultural values and merits of
Scottish people. Later on, in the sentence This is our home and I could not bear to see that home torn apart. I love this country he speaks as a citizen, as a friend who shows his deepest feelings. He is not a politician anymore, he is a voter who has children, has fear for their future and he wants the audience to feel safe with him i.e. the Union. The speaker also shows his strength, willingness to fight for something that is worthwhile-I will fight with all I have to keep us together. He is going to fight for his country, his home, although he does not mention the enemy. His sentence can also be interpreted as a threat. The word fight follows after the word love. In this part of the speech, he uses lexis which affects the pathostogetherness, national pride, bigger ideals, children, home and love for the country.

5) I want to be clear to everyone listening. There can be no complacency about the result of this referendum. The outcome is still up in the air and we have just seven months to go. Seven months to do all we can to keep our United Kingdom as one. Seven months to save the most extraordinary country in history. And we must do whatever it takes. So to everyone in England, Wales and Northern Ireland; everyone, like me, who cares about the United Kingdom, I want to say this: you don't have a vote, but you do have a voice. Those voting are our friends, neighbours and family. You do have an influence. Get on the phone, get together, email, tweet, speak. Let the message ring out from Manchester to Motherwell, from Pembrokeshire to Perth, from Belfast to Bute, from us to the people of Scotland - let the message be this: we want you to stay.

- In this last part of the speech the speaker tries to sum up all that he said before. Nothing has been decided yet; the speaker is aware that the outcome may change and he must act. He emphasizes that the voters have little time (seven months) to think about their destiny. Through all his speech he uses the pronoun we which stands for Britain and Scotland together and he leaves the impression of a person who cares a lot. Very powerful are the following verbs that he uses in imperative form for the first time of his speech- get together, email, tweet, speak - and in this way he wisely affects younger population of voters and so becomes the Minister who is very close to each generation and the one who people like. He even exaggerates in order to raise national pride and to act on pathos. Finally, Cameron ends his speech in the powerful manner by saying: We want you to stay. He again puts himself in the background showing that he is only a small person, small part of the union and gives importance only to the voters. In this last sentence, we is a pronoun standing for England, Wales and Northern Ireland and you is used for Scotland.

\section{COMPARISON OF SALMOND'S AND CAMERON'S SPEECHES}

The political speeches of both Ministers were very powerful in expressing their vision and both speakers tried to give comment on historical, present and future moments. Their political speeches are addressed to the same audience but 
differ in usage of rhetorical devices. Cameron often uses simile and idioms and Salmond metaphors but they still do not go beyond the boundaries of the given topic. At the very beginning, Salmond divided his speech into the themes and introduced each one step by step. During his speech he followed each of his points and tried to bring them close to the audience. He started his speech with negative otherpresentation, showing that the opponent's campaign is negative, destructive and that it will not underrate the strength of the democratic process. His speech was positively selforiented because he had to gain voters' attention so he focused his rhetoric on the words like economic strength, cooperation, friendly oriented nation. Under the economy topic, he gave statistical facts about unemployment rate which was falling in comparison to the one in the UK. He used "praising" rhetoric in order to attract voters and convince them that Scotland can function alone and independent. He continued his speech with expressing good faith in referendum and that Scotland and the UK would always work together constructively, in a legal and consensual way. Salmond ended his speech with negative other-presentation again. According to his metaphoric expressions, he actually wanted to prove that the government was just trying to frighten Scots by saying that there is no future for them without Britain. In his speech Salmond was always future oriented, he believed in Scotland as the independent state and the verbs "believe", "should" and "will" were used very often through his speech. They expressed his wish and hope of better future and inspired confidence. He used seldom the personal pronoun "we" and in that way did not operate effectively on the macrolevel as Cameron did. Through most of his speech he rather used pronoun "I". e.g. I want to emphasize, I believe, I will discuss the politics, I will argue... In his public address, Salmond tried to appeal to his wavering voters by stating that independence must be their future because Scotland is a strong force that can exist alone and be economically stable. Cameron's speech, on the contrary, needed no introduction and his sentences were very simple. He never insulted Salmond nor his politics. He mentioned political parties only when it came to the referendum topic. So, his speech was not directly selfpositively nor other-negatively presented. He praised the United Kingdom for economic growth it has sustained during the long history but never underestimated Scotland. Furthermore, he emphasized Scotland as a force without which the UK could not exist. Cameron's rhetoric also appealed to the emotions. He used facts and arguments about Britain and Scotland as a whole when speaking about economy, and as a good rhetorician gave justification for his political claims which Salmond lacked. He often spoke about Scotland as an important member state which Britain would not like to lose and acted on pathos more than Salmond did. In his speech Cameron mentioned the glorious Olympics in order to remind the citizens of the togetherness that they had during that time. This showed that he was not forcing voters to agree with his politics by threatening or bribing them. Instead, he gave some good encouraging reasons why only the nation as a whole can be a good nation. His part of speech about children and their future was also very emotional and appealing. There he focused more on voters' emotions, showed his concern about their children's future life and economic stability. Cameron is definitely good rhetorician and knows how to attract the masses and touch their feelings.

\section{CONCLUSION}

After analyzing the two speeches on lexical level, we can conclude that Cameron seemed to use his rhetoric and the whole situation more efficiently. He found more significant reasons for people to think and feel that staying in the Union is better for their future. He found more convincing ways to communicate to them. He came close to them by simple sentences which evoked compassion. If people are not emotionally motivated then political community lacks vitality which leads to apathy. He proved it with his rhetorical speech. It can also be concluded that the facts about economic success of the United Kingdom went in favor of Cameron. He already had facts and historical background to talk about, so he took this advantage and mentioned those facts to the voters very often. Salmond, on the other hand, had a more difficult task to do. Through the power of speech, he had to introduce citizens into a new political sphere, new situation and needed good arguments to convince voters why something new and unknown to them would be a guarantee for better life. Citizens do not like changes, especially not new challenges which can affect their economic situation. Through the persuasion, Salmond had a mission to attract their attention and convince them that only independence could bring them better future. In his speech, he lacked facts and could not lean on the history that was deeply connected to the United Kingdom. This affected Salmond's rhetoric which missed persuasiveness in comparison to Cameron.

\section{REFERENCES}

[1] T.A. Van Dijk, Elite Discourse and Racism. Newbury Park, CA, USA: Sage Publications, 1993 pp. 131-133. https://doi.org/10.4135/9781483326184

[2] R.Wodak, M.Meyer, Methods of Critical Discourse Analysis. London, England, UK: Sage Publication, 2005 pp. 3-10.

[3] T.A. Van Dijk, Ideology: A Multidisclipline Approach. London, England, UK: Sage Publication, 1998 pp.258.

[4] N. Fairclough, Language and Power (2nd ed.). Harlow: Pearson Education Limited, 2001 pp. 258

[5] N. Fairclough, Discourse and Social Change, London: Polity Press 1992 pp.37.

[6] http://www.scotland.org/about-scotland/government-timeline, accessed on 05 November 2016

[7] http://www.infoplease.com/country/united-kingdom.html, accessed on 05 November 2016

[8] http://news.scotland.gov.uk/Speeches-Briefings/First-Minister-speechFebruary-17-2014-95a.aspx, accessed on 08 November 2016

[9] http://www.newstatesman.com/politics/2014/02/george-osbornesspeech-scotland-and-pound-full-text, accessed on 09 December 2016

[10] http://www.theguardian.com/politics/2014/sep/16/cameron-milibandclegg-pledge-daily-record, accessed on 17 January 2017 